\title{
Influence of Nanoclay on the technical properties of Glass-Abaca hybrid Epoxy composite
}

\author{
Sudhagar Manickam ${ }^{1 *}$ (D), Thanneerpanthalpalayam Kandasamy Kannan² (i), \\ Benjamin Lazarus Simon ${ }^{1}$ (D), Rajasekar Rathanasamy ${ }^{3}$ (D), and Sachin Sumathy Raj ${ }^{2}$ (iD \\ 'Department of Mechanical Engineering, The Kavery Engineering College, Salem, Tamilnadu, India \\ ${ }^{2}$ Department of Mechanical Engineering, Gnanamani College of Technology, Namakkal, Tamilnadu, India \\ ${ }^{3}$ Department of Mechanical Engineering, Kongu Engineering College, Erode, Tamilnadu, India \\ *sudhagar85@gmail.com
}

\begin{abstract}
The blending of nanoclay in polymers has potential prospects in the recent development of composite technology. In this present research work, Nanoclay was added to Glass fiber and Abaca fiber reinforced hybrid epoxy composites to enhance the wear resistance of the material. Nanoclay at weight ratios of $2 \%, 4 \%, 6 \%$, and $8 \%$ was reinforced and the composite was fabricated into laminates using compression moulding. Nanoclay reinforced composites were tested for mechanical characteristics and wear rate in comparison to the non nanoclay reinforced hybrid composites. Water absorption character and morphology were also studied. It was observed that the 4\% nanoclay reinforced composites showed the optimum results, with an increase in tensile strength, flexural strength and impact strengths of $6.6 \%, 19.6 \%$, and $22.6 \%$ respectively when compared with EGA composite. Similarly the wear rate of the $4 \%$ nanoclay reinforced composite also was better than the EGA composite, showing an increase of $22.1 \%$ improved resistance.
\end{abstract}

Keywords: epoxy, hybrid composite, nanoclay, mechanical characterization, wear behavior.

How to cite: Manickam, S., Kannan, T. K., Simon, B. L., Rathanasamy, R., \& Raj, S. S. (2020). Influence of Nanoclay on the technical properties of Glass-Abaca hybrid Epoxy composite. Polimeros: Ciência Tecnologia, 30(4), e2020038. https://doi.org/10.1590/0104-1428.08520

\section{Introduction}

The trend of hybrid composites comprising of both natural and synthetic fibers have been attracting much attention among researchers lately. The addition of natural fibers in epoxy based synthetic composites helps in shifting the final component towards a much more environmental friendly product that is partially degradable ${ }^{[1]}$.

Glass fiber and Epoxy resin had been used previously to fabricate composites. Majority of these composites vary in reinfrocement weight fractions of $20 \%, 40 \%, 60 \%$ and upto $80 \%$. Various tests conducted in finding the tensile strength, impact strength, and flexural strength of the composites concluded that the material with a lower percentage of glass fiber showed lower properties. Similarly, a higher percentage of glass fiber reinforcement in epoxy resin had produce better mechanical properties ${ }^{[2,3]}$.

Epoxy-Glass fiber-Abaca composite had maximum flexural and impact strengths when compared with other hybrid composites namely, Epoxy-Glass fiber-Jute and Epoxy-Glass fiber-Jute fiber-Abaca fiber in a research carried out ${ }^{[4]}$. The glass fiber and abaca combination had showed better adhesion with epoxy than other combinations of natural and synthetic fibers. Studies on epoxy reinforced E-glass fiber and Abaca fiber hybrid composites prepared at varying ratios of $(70,20,10) \mathrm{wt} \%,(60,20,20) \mathrm{wt} \%$ and $(50,20,30) \mathrm{wt} \%$ showed that tensile properties were

best for the $(70,20,10) \mathrm{wt} \%$ composite due to the good adhesion. Similarly flexural strength was found to be best for the $(60,20,20) \mathrm{wt} \%$ composite ${ }^{[5]}$ which was due to the improved stiffness that was provided to the composite due to the increased abaca content. The hybrid composite having ratios of $50 \%$ epoxy with $50 \%$ reinforcements showed the best modulus values. Mechanical properties of the epoxy polymer showed improvement with addition of the synthetic and natural fibers due to better internal bonding of the materials ${ }^{[6]}$. Impact strength of Epoxy-glassfiber-abaca fiber hybrid composite was studied and found that $40 \%$ epoxy combined with $60 \%$ equal amount of reinforcements proved to show the best impact strength due to good absorption of impact energy by the natural fiber ${ }^{[7]}$.

However, these hybrid composites still have few drawbacks like poor wear resistance and moderate mechanical properties. The reinforcement of nanoparticles is found to be one of the promising methods to improvise the mechanical properties of a composite ${ }^{[8]}$. Nanoclay is one recent material that possesses good thermal properties, tensile strength, modulus, fire resistance and wear resistance characteristics ${ }^{[9]}$. Nanoclays are arrangements of stacked silicate layers or nanoplatelets with non-metric thickness and have diameters ranging between 50 to $200 \mathrm{~nm}$. Different types of nanoclays are Montmorillonite (MMT), kaolinite, and saponite. MMT 
nanoclay is commonly preferred in industries because of its availability, cost-effectiveness and simple processing ability ${ }^{[10]}$. MMT has a structure of layered phyllosilicates which when arranged in the ratio of 2:1 gives an extract of Cloisite 30B and Cloisite 20A. Among these derivatives the Cloisite $20 \mathrm{~A}$ is more economically available. It is an organically modified Montmorillonite (OMMT) which shows strong antimicrobial activity against all kinds of bacteria $^{[11]}$. This factor also helps to support the natural fiber reinforcement in a hybrid composite material form bacterial decay. Nanoclay had shown good adherence with epoxy. compositions of $0.5,1,1.5,2$ parts per hundred resin (phr) of nanoclay with epoxy which showed an optimum increase of tensile strength, flexural strength and thermal properties of the polymer ${ }^{[8]}$. Nanoclay at both reinforcement levels of $5 \%$ and $10 \%$ proved to produce better mechanical properties when combined with epoxy than with polyester resin in a study carried out ${ }^{[12]}$. Mechanical and tribological behavior of nanoclay reinforced Glass fiber-epoxy composite at reinforcement ratios of $0 \%, 1 \%, 3 \%, 5 \%$ and $7 \%$ by weight resulted in the $5 \mathrm{wt} \%$ of nanoclay reinforced composites showing good wear behavior due to the low specific wear rate ${ }^{[13]}$.

Composites prepared with varying in different weight percentage of $3 \%, 5 \%, 7 \%$, and $10 \%$ nanoclay reinforcements. The results showed that an increase in the weight percentage beyond $5 \%$ reduced the strength of the final composite product ${ }^{[14]}$. Similarly, $3 \%$ of nanoclay loading had produced the maximum mechanical properties when compared to the other percentage of reinforcements ${ }^{[15]}$.

In industries, hybrid polymer composites have increasing usage in sliding and rolling applications like bearings, seals, gears, rollers, wheels, clutches and cams ${ }^{[16]}$. Reducing wear rate is therefore an important factor while fabricating such components $^{[17]}$. In this present work, Cloisite 20A MMT nanoclay was dispersed with Epoxy resin and hybrid composites were fabricated by reinforcing Glass fiber and Abaca fiber at equal weight ratios. The technical properties of the nanoclay reinforced hybrid composites were compared with that of plain Epoxy polymer, Epoxy-Glass fiber composite and Epoxy Glass fiber Abaca fiber composite to study the enhancement in the properties.

\section{Materials and Methods}

\subsection{Materials}

In this present work, an Epoxy resin - LY556 DGEBA of density $1.16 \mathrm{~g} / \mathrm{cm}^{3}$, curing time and temperature are $8 \mathrm{hrs}$ and $140^{\circ} \mathrm{C}$, with Hardener- HY951 Triethylenetetramine of density $0.95 \mathrm{~g} / \mathrm{cm}^{3}$ was used and purchased from Sri Sakthi Enterprises, Chennai, India. E-Glass fiber mat of thickness $1 \mathrm{~mm}$ and density $2.6 \mathrm{~g} / \mathrm{cm}^{3}$ was purchased from Sri Sakthi Enterprises, Chennai, India. Abaca (Manila hemp) of fiber diameter 260 microns, thickness $1 \mathrm{~mm}$, and its density $1.5 \mathrm{~g} / \mathrm{cm}^{3}$ purchased from Go Green Products, Chennai, India in the form of plain fabric mat. Cloisite 20A MMT Nanoclay of density $1.7 \mathrm{~g} / \mathrm{cm}^{3}$, and dry powder 500 mesh with pass rate $\geq 95 \%$ was purchased from Ultrananotech Pvt. Ltd, Bangalore, India.

\subsection{Fabrication method}

In the first step a mica sheet was placed at the bottom of a mold of size $300 \times 300 \mathrm{~mm}$, and a coat of wax was applied throughout the mold for easy removal of the composite. Epoxy resin and the hardener were combined in a ratio of 10:1. To fabricate the S3 composite, in the first step Glass fiber mat was placed at the bottom of the mold and epoxy applied onto it. Secondly abaca fiber mat was placed, followed by applying epoxy. The procedure was followed until three alternative layers each of glass fiber and abaca fiber were sandwithced with the help of epoxy resin through handlay up method. The laminated composite was then compression molded for 4 hours under a compression load of 1000 N. Post compression, the composite was allowed to cure for 48 hours at room temperature. After curing, the test specimens were cut down from the laminated slabs using water jet machining to ASTM standard dimensions. $\mathrm{S} 1$ and $\mathrm{S} 2$ specimens were fabricated in the similar fashion. All the test specimens were fabricated to an even thickness of $4 \mathrm{~mm}$ as represented in Figure 1.

For the preparation of the nano clay reinforced hybrid composites, the nanoclay was initally dried in an oven at a temperature of $90^{\circ} \mathrm{C}$ for 5 hours to remove all moisture. Epoxy was heated to $80{ }^{\circ} \mathrm{C}$ to reduce its viscosity ${ }^{[8]}$ and measured quantity of the dried nanoclay as represented in Table 1 was added to it and stirred at $600 \mathrm{rpm}$ mechanically for about 30 minutes $^{[13]}$. The mixture was then placed in a high-intensity ultrasonicator at $300 \mathrm{rpm}$ for 30 minutes ${ }^{[13,18]}$. The curing reagent was then mixed at 1 part to 10 parts of the epoxy-nanoclay mixture. Fabrication of the Epoxy-GlassAbaca +Nano clay followed similar methods of fabrication of the $\mathrm{S} 3$ composite laminates, with the nanoclay content varying at 2, 4, 6 and $8 \mathrm{wt} \%$.

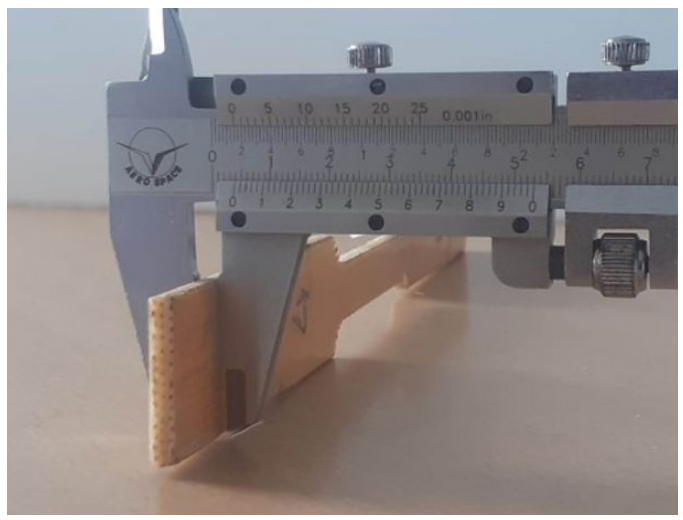

Figure 1. Thickness of the composite laminate.

Table 1. Sample code for all the specimens.

\begin{tabular}{ccccc}
\hline $\begin{array}{c}\text { Sample } \\
\text { Code }\end{array}$ & $\begin{array}{c}\text { Epoxy } \\
\text { resin } \\
\text { (wt\%) }\end{array}$ & $\begin{array}{c}\text { Glass } \\
\text { Fibre } \\
\text { (wt\%) }\end{array}$ & $\begin{array}{c}\text { Abaca } \\
\text { fibre } \\
\text { (wt\%) }\end{array}$ & $\begin{array}{c}\text { Nano clay } \\
\text { (wt\%) }\end{array}$ \\
\hline S1 & 100 & 0 & 0 & 0 \\
S2 & 75 & 25 & 0 & 0 \\
S3 & 50 & 25 & 25 & 0 \\
S4 & 48 & 25 & 25 & 2 \\
S5 & 46 & 25 & 25 & 4 \\
56 & 44 & 25 & 25 & 6 \\
S7 & 42 & 25 & 25 & 8 \\
\hline
\end{tabular}




\subsection{Experimentation and Methodology:}

All the test specimens were machined to dimensions and tested to ASTM standards considering ASTM D638 for tensile test, D790 for flexural test, and D256 for impact test ${ }^{[19,20]}$. Tensile and flexural tests were carried out at $10 \mathrm{KN}$ load capacity and a Crosshead speed of $2 \mathrm{~mm} / \mathrm{min}$ on a Universal Testing Machine (Model: INSTRON-3365). Unnotched test specimens were tested on an Izod impact testing machine using a hammer head of 25 Joules impact force and the test specimes underwent complete fracture. Wear test specimens were punched to a diameter of $15.8 \mathrm{~mm}$. Pin on-Drum method was adopted to analyse the wear rate. The drum had a cylinder size of $150 \mathrm{~mm}$ diameter and $500 \mathrm{~mm}$ length. The coarser Abrasive sheet (Grade 60) layer on the drum was made to rotate at $40 \mathrm{rpm}$ with a load of $1 \mathrm{~kg}$ to test the rate of wear on the specimens. Water uptake for all the samples was carried out by initially measuring their dry weight $\left(\mathrm{W}_{\mathrm{d}}\right)$. The samples were then immersed in water for 48 hours at room temperature. After the immersion period the samples were measured for the change in their weight, which is the wet weight $\left(\mathrm{W}_{\mathrm{w}}\right)$. Finally the percentage of water uptake $(\% \mathrm{WA})$ was calculated using the formula shown in Equation 121].

$$
\% W A=\left[\frac{W_{w}-W_{d}}{W_{d}}\right] \times 100
$$

Morphology was studied on the fractured surface of all the specimens using Scanning Electron Microscope (Model: MIRA 3 TESCAN) at $3500 \mathrm{X}$ magnification and a scale of 10 microns.

\section{Results and Discussions}

\subsection{Mechanical analysis}

Figure $2 \mathrm{a}$ and $2 \mathrm{~b}$ show the variation of the tensile strength and tensile modulus of the various samples in this research. The tensile strength and tensile modulus of S2 were $144.67 \%$ and $105.47 \%$ higher than S1, due to the reinforcement of the glass fiber. S3 produced $167.60 \%$ and $131.70 \%$ higher values than $\mathrm{S} 1$, and $9.37 \%$ and $12.76 \%$ higher values than the $\mathrm{S} 2$ due to the hybridization of glass fiber and abaca fiber reinforcements as intimated in many literatures. Initial addition of nanoclay, in the S1 specimen showed marginal improvement in the tensile properties, this pattern followed for $\mathrm{S} 5$ which showed further increase in the tensile properties. Beyond $4 \mathrm{wt} \%$ reinforcement of nanoclay the tensile properties for the S6 and S7 composites showed reduced patterns.

Figure $3 a$ and $3 b$ shows that the Variation of flexural strength and flexural modulus with the different compositions of composites. The flexural strength and flexural modulus of $\mathrm{S} 2$ composite was $34.25 \%$ and $37.48 \%$ greater than $\mathrm{S} 1$. S3 composite had produced flexural strength and flexural modulus of $54.20 \%$ and $57.42 \%$ higher than S1, $14.85 \%$ and $14.50 \%$ higher than $\mathrm{S} 2$ composite. Flexural properties of the nanoclay reinforced compsoties showed replicated similar fashion as obtained for the tensile properties. S5
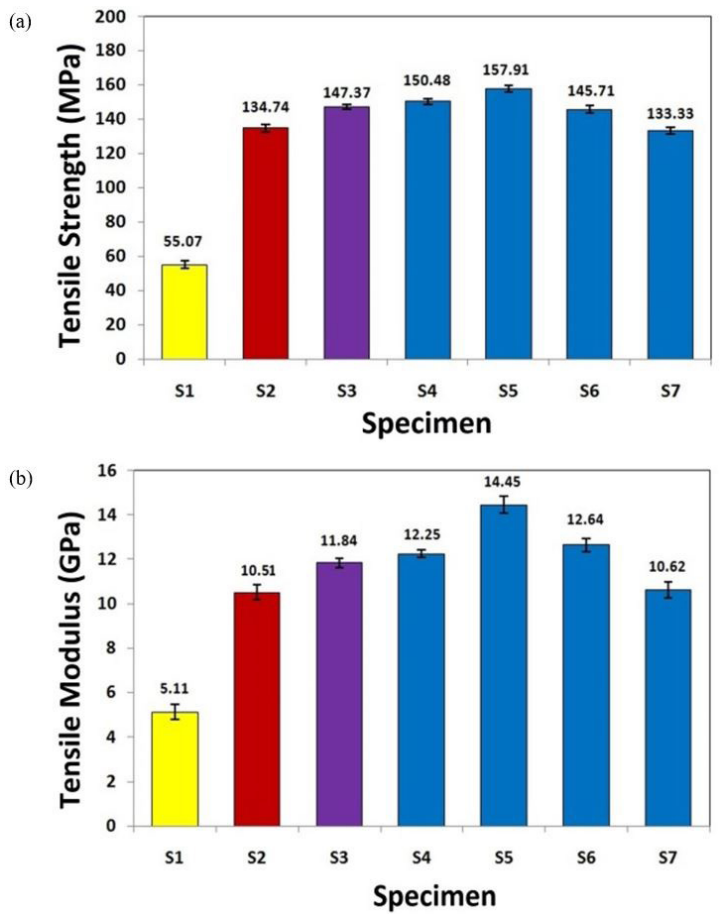

Figure 2. (a) Variation of Tensile Strength with the different Compositions; (b) Variation of Tensile Modulus with the different Compositions.

(a)

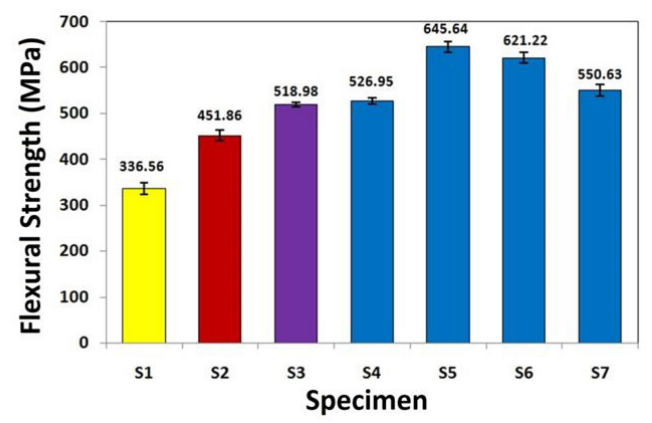

(b)

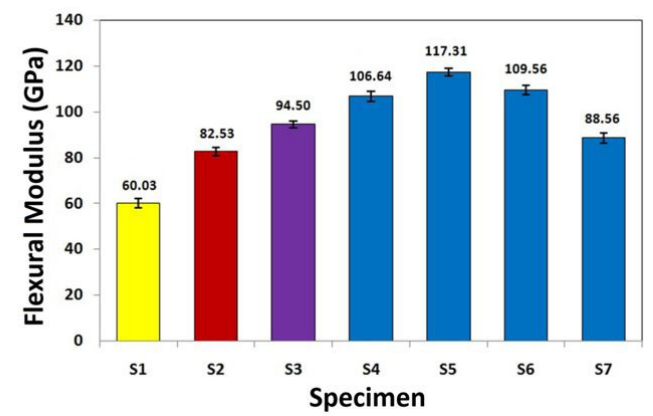

Figure 3. (a) Variation of Flexural Strength with the different Compositions; (b) Variation of Flexural Modulus with the different Compositions.

composite showed the best trend in flexural strength and flexural modulus among the different nanoclay reinforced composites showing $91.83 \%$ and $95.41 \%$ higher values than S1, $42.88 \%$ and $42.14 \%$ higher than S2, and $24.40 \%$ and $24.13 \%$ higher than $\mathrm{S} 3$ composites respectively. 
The tensile and flexural properties in common for S2 were higher than S1 because the reinforced glass fiber had acted as the main load carrying agent in the composite thereby improving the mechanical character of the Epoxy matrix $^{[22]}$. Similarly, S3 composite had an increase in the trend of tensile and flexural properties when compared with S1 and S2. This was due to fact that synthetic fiber and natural fiber combination exhibits better results than individual type fiber reinforced composites ${ }^{[4,23]}$. Comparing the S4, S5, S6 and S7, the best tensile strength and tensile modulus were attained for the S5 composite. S5 showed $7.14 \%$ and $22.04 \%$ increase in the tensile strength and tensile modulus when compared with the values of S3. Commonly, the test results showed that the addition of nanoclay up to $4 \mathrm{wt} \%$, elevated the properties to the maximum level. The increase in the tensile strength, tensile modulus, flexural strength, and flexural modulus can be attributed due to the high surface area of nanoclay content that can lead to homogenous distribution in epoxy resin ${ }^{[13,24,25]}$.

On the other hand, the properties of the composites had drop beyond $4 \mathrm{wt} \%$ addition of nanoclay reinforcement, because the epoxy resin could not accommodate an impregnation of high nanoclay content. A few portion of nanoclay platelets were not homogenously dispersed and had led to agglomeration ${ }^{[18,26,27]}$. The agglomerated nanoclay platelets form weaker spots in the epoxy resin, and this leads to sudden crack initiation and propagation phenomenon, thereby causing a decrease in mechanical properties ${ }^{[12,24]}$.

Variation of impact strength with the different compositions of composites is shown in Figure 4. Impact strength of S2 composite was $90.47 \%$ higher than S1. S3 composite produced $100.12 \%$ higher impact resistance than $\mathrm{S} 1$ and $5.00 \%$ higher than the S2 composite. S5 showed $158.50 \%$ higher impact strength than S1, 35.71\% higher values than $\mathrm{S} 2$ and $29.25 \%$ higher impact resistance than S3 composite. This was because of the better impact resistance nature of nanoclay and good stress energy transfer between the matrix and fiber materials ${ }^{[18,28]}$. S6 and S7 composites showed lower impact strengths due to brittle fracture that had occurred in the specimens. This led to lower impact strengths and reduced stiffness of the composite when compared to the S5 composite.

SEM image Figure 5a and 5b showed that the tensile and flexural properties of S2 were higher than S1 because of reinforcement of glass fiber. Comparing the SEM

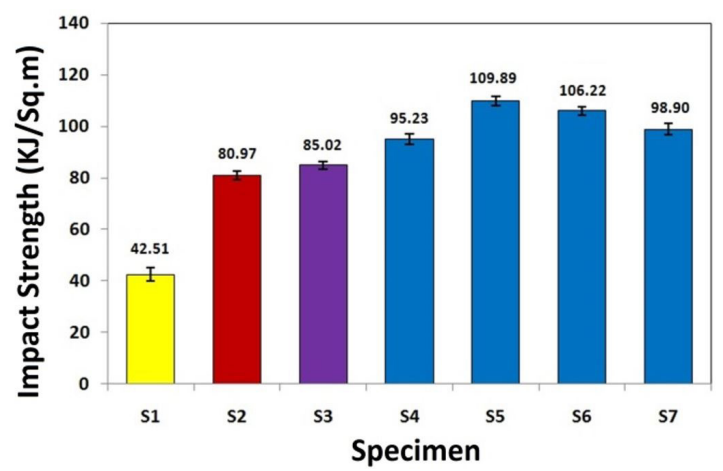

Figure 4. Variation of Impact Strength with the different Compositions. image of Figure $5 \mathrm{c}$ with Figure $5 \mathrm{a}$ and $5 \mathrm{~b}$, the presence of synthetic fiber and natural fiber combination exhibits better results than individual type fiber reinforced composites. The good bonding of the composite was also visible in the SEM image Figure 5d. The agglomerated distribution of high nanoclay content in between the matrix and fiber pores decreased the ability of the composite to transfer the impact energy efficiently by resulting in internal flaws as seen in the SEM image Figure 5e.

\subsection{Wear rate}

Specimens of S1, S2, S3, S4, S5, S6, and S7 were dimensionally prepared for the wear testing. Figure 6 shows that the Variation of wear rate with the different compositions of composites.

From the tested results, wear rate of the $\mathrm{S} 1$ and $\mathrm{S} 2$ composite are $0.1882 \mathrm{~g} / \mathrm{m}$ and $0.1638 \mathrm{~g} / \mathrm{m}$ respectively. When comparing the $\mathrm{S} 1$ with the $\mathrm{S} 2$ composite, $\mathrm{S} 2$ produced wear rate of $12.96 \%$ lower than S1 because of the Glass fiber reinforcement ${ }^{[17]}$. The hardness of glass fiber was 94 RHN and the hardness of plain Epoxy was 76 RHN when measured using a Rockwell hardness testing machine. The hardness parameters prove that the harder glass fiber that was reinforced into the matrix resulted in higher wear resistance of the composite.

The wear rate of S3 composite was $0.1266 \mathrm{~g} / \mathrm{m}$. When comparing the $\mathrm{S} 3$ composite with $\mathrm{S} 1$ and $\mathrm{S} 2$, the $\mathrm{S} 3$ showed $32.73 \%$ and $22.71 \%$ lower than S1 and S2 composites respectively. The chemical composition of natural fiber emphasizes fiber properties in the composites ${ }^{[29]}$. While comparing the chemical composition of abaca with the other commonly used natural fiber reinforcement like hemp fiber, areca fiber, jute, sisal, flax and other banana fibers, the abaca fiber inherits a higher content of $66.43 \%$ cellulose, $30 \%$ hemicellulose, and $13.6 \%$ lignin. Cellulose is one of the important factors which can be produced strengthens and stability to the cell walls and fiber. It is rigid, high crystalline, and un dissolved in an organic solvent ${ }^{[5]}$.

This factor justifies that the chemical composition present in natural fibers may have supported in lowering the wear rate of the natural fiber reinforced hybrid composites. Reinforcement of nanoclay in general, further reduced the wear rate of the hybrid composite. Addition of nanoclay lowered the wear rate of the hybrid composite to $0.1124 \mathrm{~g} / \mathrm{m}$. The S5 composite which had the best performance in the mechanical properties had a wear rate of $0.0986 \mathrm{~g} / \mathrm{m}$. This was because nanoclay has the inherent property to withstand high frictional stress ${ }^{[17,27]}$. Increasing nanoclay content showed further reduction in wear rate of the composites. The S7 composite which had the highest nanoclay content resulted in a wear rate of $0.0864 \mathrm{~g} / \mathrm{m}$ showing the highest resistance to abrasion among all the test specimens in this study ${ }^{[30]}$.

\subsection{Water absorption analysis}

Figure 7 shows that the percentage of water absorbed by the different specimens. The water absorption of both the plain Epoxy polymer and the S2 composite were zero since they are both synthetic materials.

The addition of Abaca fiber showed water absorption of $0.75 \%$ since a natural fiber has the tendency to absorb 


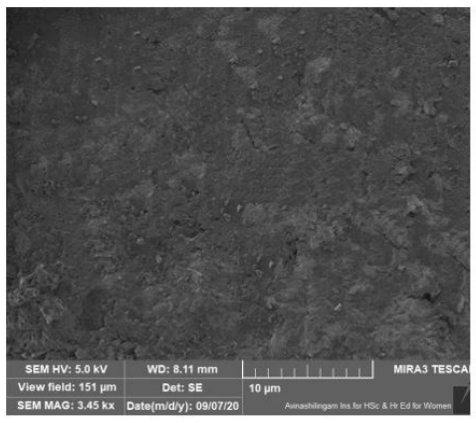

(a)

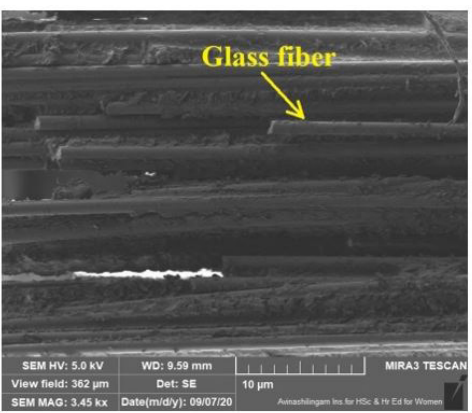

(b)

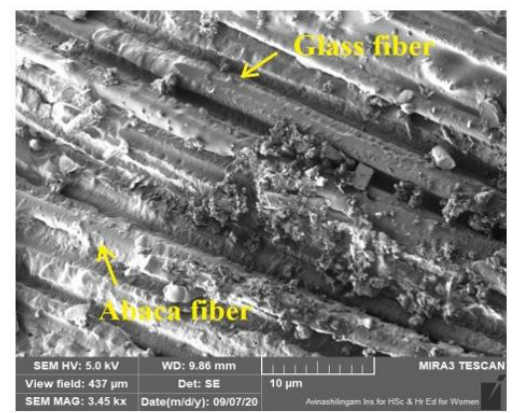

(c)

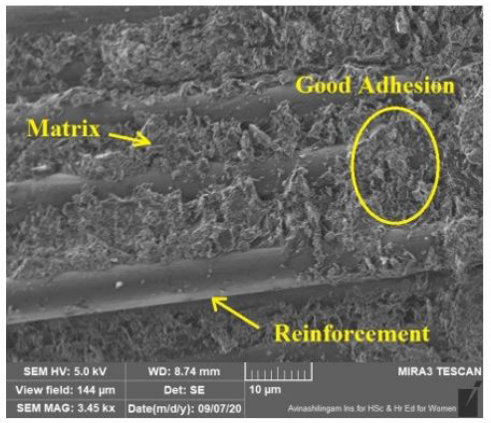

(d)

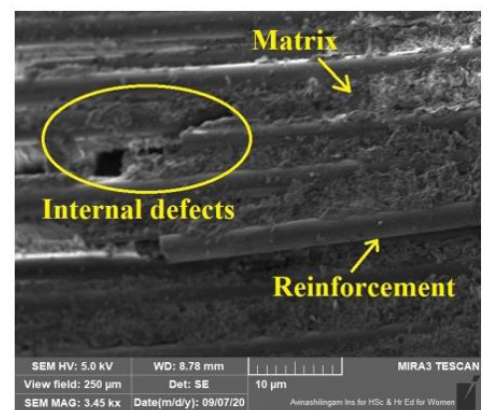

(e)

Figure 5. SEM images of (a) S1, (b) S2, (c) S3, (d) S5 and (e) S6 composites.

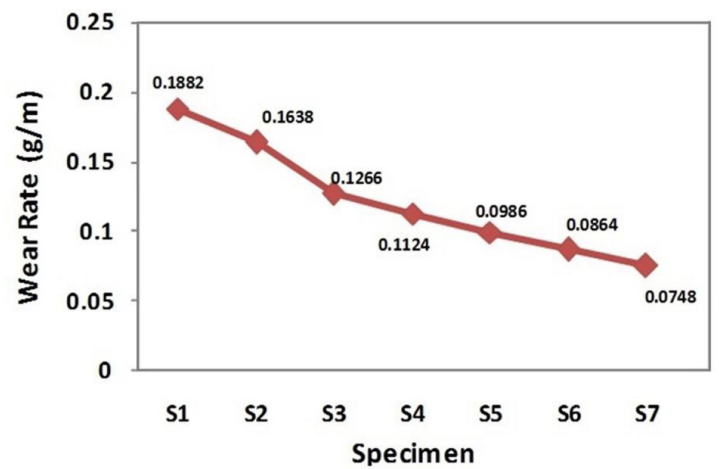

Figure 6. Wear rate of the Specimen.

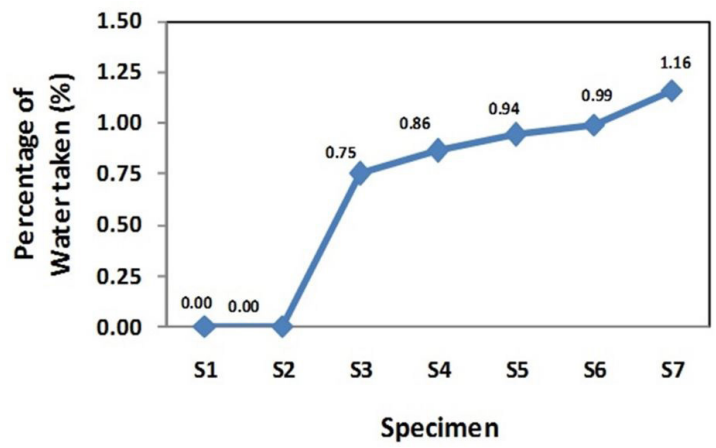

Figure 7. Percentage of water taken for different Specimen. moisture ${ }^{[21]}$. The increase in nanoclay reinforcement showed further increase in moisture absorption. The S5 composite which had the best mechanical properties showed water absorption of $0.94 \%$. S7 with the maximum amount of nanoclay content, resulted with a moisture absorption of $1.16 \%$. This was due to the fact that nanoclay tends to absorb water ${ }^{[10]}$.

\section{Conclusions}

The addition of nanoclay to the hybrid composite containing Epoxy matrix with Glass fiber and Abaca fiber reinforcements, showed improved mechanical properties in general. The mechanical analysis carried out to determine the tensile, flexural and impact properties resulted in the $4 \%$ nanoclay reinforced hybrid composite having the best characteristics. The maximum increase in tensile strength, flexural strength and impact strength for EGA $+4 \%$ showed an increase by $6.6 \%, 19.6 \%$ and $22.6 \%$ respectively when compared with EGA. Wear property of the nanoclay reinforced composites were also found to be better than the composites without nanoclay reinforcements. The wear resistance of the EGA $+4 \%$ composite, that had the best mechanical properties in this research was $22.1 \%$ more efficient than the EGA composite. $4 \%$ nanoclay reinforcement provided the most optimum and improvised technical properties through this research. 


\section{References}

1. Parmar, R. K., \& Saladi, S. P. (2018). Study on mechanical properties of natural/syntheticfibrereinforced polymer hybrid composite: a review. International Journal of Scientific Research in Science, Engineering and Technology, 4(1), 1472-1477. Retrieved in 2020, September 15, from http://ijsrset.com/ IJSRSET2184130

2. Prasad, T., Reddy, A. C. K., Reddy, S. M., \& Arjun, N. (2013). Experimental investigation of mechanical behaviour of glass-epoxy composites. In Proceedings of the 3rd International Conference On Recent Advances in Material Processing Technology (pp. 1-11). Kovilpatti, India: Society for Manufacturing Engineers, National Engineering College.

3. Tyagi, S., Kumar, S., \& Rakesh. (2018). Experimental and numerical analysis of tensile strength of unidirectional glass/ epoxy composite laminates with different fiber percentage. International Journal of Applied Engineering Research, 13(15), 12157-12160. Retrieved in 2020, September 15, from https:// www.ripublication.com/ijaer18/ijaerv13n15_64.pdf

4. Vijaya Ramnath, B., Junaid Kokan, S., Niranjan Raja, R., Sathyanarayanan, R., Elanchezhian, C., Rajendra Prasad, A., \& Manickavasagam, V. M. (2013). Evaluation of mechanical properties of abaca-jute-glass fibre reinforced epoxy composite. Materials \& Design, 51, 357-366. http://dx.doi.org/10.1016/j. matdes.2013.03.102.

5. Ramadevi, P., Dhanalakshmi, S., Basavaraju, B., Raghu Patel, G. R., Pramod, V. B., \& Chikkol Venkateshappa, S. (2014). Abaca fiber reinforced hybrid composites. International Journal of Applied Engineering Research, 9(23), 20273-20286. Retrieved in 2020, September 15, from https://www.ripublication.com/ ijaer\%208/ijaerv9n23_200.pdf

6. Venkatasubramanian, H., Chaithanyan, C., Raghuraman, S., \& Panneerselvam, T. (2014). Evaluation of mechanical properties of abaca-glass-banana fiber reinforced hybrid composites. International Journal of Innovative Research in Science, Engineering and Technology, 3(1), 8169-8177. Retrieved in 2020, September 15, from https://www.ijirset. com/upload/2014/january/14_EVALUATION.pdf

7. Vishal, A., Vinay, B. G., \& Rajeev, K. T. (2019). Abaca glass fiber reinforced composite materials. International Research Journal of Engineering and Technology, 6(5), 53-58. Retrieved in 2020, September 15, from https://www.irjet.net/archives/ V6/i5/AIME-2019/AIME-09.pdf

8. Mustapha, R., Razak Rahmat, A., Abdul Majid, R., \& Noor Hidayah Mustapha, S. (2018). Mechanical and thermal properties of montmorrillonite nanoclay reinforced epoxy resin with bio-based hardener. Materials Today Proceedings, 5(10), 21964-21972. http://dx.doi.org/10.1016/j.matpr.2018.07.057.

9. Yadav, S. M., \& Yusoh, K. B. (2019). Sub-surface mechanical properties and sub-surface creep behavior of wood-plastic composites reinforced by organoclay. Science and Engineering of Composite Materials, 26(1), 114-121. http://dx.doi.org/10.1515/ secm-2016-0291.

10. Kanmani, P., \& Rhim, J.-W. (2013). Physical, mechanical and antimicrobial properties of gelatin based active nanocomposite films containing AgNPs and Nanoclay. Food Hydrocolloids, 35, 644-652. http://dx.doi.org/10.1016/j.foodhyd.2013.08.011.

11. Hosseini, H., Shojaee-Aliabadi, S., Hosseini, S. M., \& Mirmoghtadaie, L. (2017). Nanoantimicrobials in food industry. In A. E. Oprea, \& A. M. Grumezescu (Eds.), Nanotechnology applications in food: flavor, stability, nutrition and safety (Chap. 11, pp. 223-243). UK: Academic Press. http://dx.doi. org/10.1016/B978-0-12-811942-6.00011-X.

12. Shettar, M., Achutha Kini, U., Sharma, S. S., \& Hiremath, P. (2017). Study on mechanical characteristics of nanoclay reinforced polymer composites. Materials Today Proceedings, 4(10), 11158-11162. http://dx.doi.org/10.1016/j.matpr.2017.08.081.

13. Nayak, S., Nayak, R. K., Panigrahi, I., \& Sahoo, A. K. (2019). Tribo-mechanical responses of glass fiber reinforced polymer hybrid nanocomposites. Materials Today Proceedings, 18(7), 4042-4047. http://dx.doi.org/10.1016/j.matpr.2019.07.347.

14. Sankaran, K., Manoharan, P., Chattopadhyay, S., Nair, S., Govindan, U., Arayambath, S., \& Nando, G. B. (2016). Effect of hybridization of organoclay with carbon black on the transport, mechanical, and adhesion properties of nanocomposites based on bromobutyl/epoxidized natural rubber blends. RSC Advances, 6(40), 33723-33732. http://dx.doi.org/10.1039/C5RA25970C.

15. Kumar, S., Nando, G. B., Nair, S., Unnikrishnan, G., Sreejesh, A., \& Chattopadhyay, S. (2015). Effect of organically modified montmorillonite clay on morphological, physicomechanical, thermalstability, and watervapor transmission rate properties of BIIR-CO rubber nanocomposite. Rubber Chemistry and Technology, 88(1), 176-196. http://dx.doi.org/10.5254/ rct.14.85996.

16. Nuruzzaman, D. M., \& Chowdhury, M. A. (2012). Friction and wear of polymer and composites. In N. Hu (Ed.), Composites and their properties (pp. 299-330). UK: InTechOpen. http:// dx.doi.org/10.5772/48246.

17. Vijay, B. R., \& Srikantappa, A. S. (2019). Physico-mechanical and tribological properties of glass fiber based epoxy composites. International Journal of Mechanical Engineering and Robotics Research, 8(6), 929-934. http://dx.doi.org/10.18178/ ijmerr.8.6.929-934.

18. Binu, P. P., George, K. E., \& Vinodkumar, M. N. (2016). Effect of Nanoclay, Cloisite 15A on the mechanical properties and thermal behavior of glass fiber reinforced polyester. Procedia Technology, 25, 846-853. http://dx.doi.org/10.1016/j. protcy.2016.08.191.

19. Chandramohan, D., \& Presin Kumar, A. J. (2017). Experimental data on the properties of natural fiber particle reinforced polymer composite material. Data in Brief, 13, 460-468. http://dx.doi. org/10.1016/j.dib.2017.06.020. PMid:28702485.

20. Sachin, S. R., Kannan, T. K., \& Rajasekar, R. (2020). Effect of wood particulate size on the mechanical properties of PLA biocomposite. Pigment \& Resin Technology, 49(6), 465-472. http://dx.doi.org/10.1108/PRT-12-2019-0117.

21. Raj, S. S., Kannan, T. K., \& Rajasekar, R. (2020). Influence of prosopis juliflora wood flourin poly lactic acid-developing a novel bio-wood plastic composite. Polímeros: Ciência e Tecnologia, 30(1), e2020012. http://dx.doi.org/10.1590/01041428.00120 .

22. Abdel-Rahim, R. H., Hasan, A. M., \& Hussein, A. K. (2015). Mechanical properties of epoxy based hybrid composites reinforced by glass fibers and sic particles. The Iraqi Journal for Mechanical and Material Engineering, 15(1), 66-79. Retrieved in 2020, September 15, from https://www.iasj.net/ iasj/download/b8781a4891e35f3e

23. John, K., \& Naidu, S. V. (2004). Tensile properties of unsaturated polyester-based sisal fiber-glass fiber hybrid composites. Journal of Reinforced Plastics and Composites, 23(17), 18151819. http://dx.doi.org/10.1177/0731684404041147.

24. Shokrieh, M. M., Kefayati, A. R., \& Chitsazzadeh, M. (2012). Fabrication and mechanical properties of clay/epoxy nanocomposite and its polymer concrete. Materials \& Design, 40, 443-452. http://dx.doi.org/10.1016/j.matdes.2012.03.008.

25. Saeed, K., \& Khan, I. (2015). Characterization of clay filled poly (butylene terephthalate) nanocomposites prepared by solution blending. Polímero: Ciência e Tecnologia, 25(6), 591-595. http://dx.doi.org/10.1590/0104-1428.2039.

26. Alsagayar, Z. S., Rahmat, A. R., Arsad, A., \& Binti Mustaph, S. N. H. (2015). Tensile and flexural properties of montmorillonite 
Nanoclay reinforced epoxy resin composites. Advanced Materials Research, 1112, 373-376. http://dx.doi.org/10.4028/ www.scientific.net/AMR.1112.373.

27. Shettar, M., Kowshik, C. S. S., Manjunath, M., \& Hiremath, P. (2020). Experimental investigation on mechanical and wear properties of Nanoclay-epoxy composites. Journal of Materials Research and Technology, 9(4), 9108-9116. http:// dx.doi.org/10.1016/j.jmrt.2020.06.058.

28. Mylsamy, B., Palaniappan, S. K., Pavayee Subramani, S., Pal, S. K., \& Aruchamy, K. (2019). Impact of Nanoclay on mechanical and structural properties of treated Coccinia indica fibre reinforced epoxy composites. Journal of Materials Research and Technology, 8(6), 6021-6028. http://dx.doi. org/10.1016/j.jmrt.2019.09.076.
29. Sachin, S. R., Kannan, T. K., Babu, M., \& Vairavel, M. (2019). Processing and testing parameters of PLA reinforced with natural plant fiber composite materials - a brief review. International Journal of Mechanical and Production Engineering Research and Development, 9(2), 933-940.

30. Uygunoglu, T., Brostow, W., \& Gunes, I. (2015). Wear and friction of composites of an epoxy with boron containing wastes. Polímeros: Ciência e Tecnologia, 25(3), 271-276. http://dx.doi.org/10.1590/0104-1428.1780.

Received: Sept. 24, 2020

Revised: Nov. 20, 2020

Accepted: Dec. 10, 2020 